Portland State University

PDXScholar

Sociology Faculty Publications and

Presentations

Sociology

$2-1-2012$

\title{
Weak Coffee: Certification and Co-Optation in the Fair Trade Movement
}

Daniel Jaffee

Portland State University, jaffee@pdx.edu

Follow this and additional works at: https://pdxscholar.library.pdx.edu/soc_fac

Let us know how access to this document benefits you.

\section{Citation Details}

Published as: Jaffee, D. (2012). Weak coffee: Certification and co-optation in the fair trade movement. Social Problems, 59(1), 94-116.

This Post-Print is brought to you for free and open access. It has been accepted for inclusion in Sociology Faculty Publications and Presentations by an authorized administrator of PDXScholar. Please contact us if we can make this document more accessible: pdxscholar@pdx.edu. 


\title{
WEAK COFFEE: CERTIFICATION AND COOPTATION IN THE FAIR TRADE MOVEMENT
}

\author{
Daniel Jaffee ${ }^{1}$
}

This is an Accepted Manuscript of an article published in the journal Social Problems on February 1, 2012. Available online: https://doi.org/10.1525/sp.2012.59.1.94

Citation: Daniel Jaffee. 2012. "Weak Coffee: Certification and Co-optation in the Fair Trade Movement." Social Problems 59 (1): 94-116. Doi: 10.1525/sp.2012.59.1.94

\begin{abstract}
The sociological literature on social movement organizations (SMOs) has come to recognize that under neoliberal globalization many SMOs have moved from an emphasis on the state as the locus of change toward a focus on corporations as targets. This shift has led some SMOs to turn to forms of market-based private regulatory action. The use of one such tacticvoluntary, third-party product certification - has grown substantially, as SMOs seek ways to hold stateless firms accountable. This article explores the case of the international fair trade movement, which aims to change the inequitable terms of global trade in commodities for small farmers, artisans, and waged laborers. Drawing from interviews with a range of fair trade participants, document analysis, and media coverage, the article describes fair trade's growing relationship with multinational coffee firms, particularly Starbucks and Nestlé. It explores intramovement conflicts over the terms for and the effects of corporate participation in fair trade, and illuminates tensions between conceptualizations of fair trade as movement, market, and system. The article makes two arguments. First, while fair trade has succeeded partially in reembedding market exchange within systems of social and moral relations, it has also proved susceptible to the power of corporate actors to disembed the alternative through a process of movement cooptation. Second, it argues that co-optation takes a unique form in the context of social movements whose principal tools to achieve social change are certification and labeling: it occurs primarily on the terrain of standards, in the form of weakening or dilution.
\end{abstract}

\footnotetext{
${ }^{1}$ Department of Sociology, Portland State University, Portland, OR, USA. Email: jaffee@pdx.edu
} 


\section{Weak Coffee: Certification and Cooptation in the Fair Trade Movement \\ Daniel Jaffee}

How much difference does a decade make for a social movement? In April 2000, stung by charges of labor rights violations on its Central American coffee plantations and facing a threat of large-scale protests and a boycott by the human rights organization Global Exchange and other groups, Starbucks - the largest specialty coffee roaster-capitulated to activist demands (James 2000). The company agreed to sell fair-trade certified coffee at all 2,300 of its U.S. cafes, albeit initially purchasing less than one percent of its overall supply (Starbucks 2001). By 2009, Starbucks - which had since mushroomed to 11,000 stores in the U.S. alone-was purchasing 39 million pounds of fair-trade coffee, over 10 percent of its total volume (Starbucks 2010). Moreover, several of the firm's competitors had followed suit, including the world's largest coffee trader, Nestlé. By all appearances, this was a remarkably successful case of a social movement mobilizing consumer pressure and market tactics to hold a major transnational corporation accountable for the social effects of its commercial practices. Yet these developments have also proved quite controversial. The U.S. fair trade movement has over the past decade experienced increasingly serious divisions, centered precisely on the nature of its relationship to the large firms that have contributed to the dramatic growth of fair trade sales.

The sociological literature on social movement organizations (SMOs) has recognized that over the past two decades, many SMOs have shifted from a nearly exclusive emphasis on the state as a locus of change toward a focus on corporations as targets (Pellow 2001; Van Dyke, Soule, and Taylor 2004). This shift has been accompanied by the rise of corporate campaigning tactics, such as those employed by the movement against genetically engineered foods (Schurman 2004, 2010; Weber, Thomas, and Rao 2009), anti-sweatshop movements (Klein 
1999; Seidman 2007), campaigns targeted at specific corporations' contribution to climate change (Trumpy 2008), and movements against tropical deforestation (Bartley 2007a; Klooster 2005). This phenomenon is typically framed as an artifact both of a neoliberal turn away from strong state regulation, and of processes of economic globalization that have extended the scale of economic activity in many cases beyond the reach of national governments, with transnational corporations wielding greatly increased power relative to states (McMichael 2007). The new reality has also been marked by the rise of new forms of private regulation and suprastate governance (Busch and Bain 2004; Mutersbaugh 2005b). The use of one such form of marketbased nonstate regulation — voluntary product certification — has grown substantially in recent years, as social movements seek ways to hold increasingly mobile or stateless firms accountable.

Yet how should one theorize a social movement that aims to transform the social conditions of production across global industries, but, rather than pushing firms to change their behavior with campaigning tactics, utilizes voluntary certification as its primary tool, in an effort to simultaneously recruit and regulate powerful economic actors? And how ought we to understand the ways in which capital responds to such initiatives that aim to tame the excesses of unregulated markets through the workings of the market (Brown 1993)—responses that may instead have the effect of taming the social movement itself?

This article explores the case of the international fair trade movement, a coalition comprised of a broad range of activists, traders, retailers, producer organizations, nongovernmental organizations (NGOs), certifiers and consumers in more than 70 countries. Historically, the movement's central premises have been commitments to guaranteed minimum commodity prices to address volatile terms of trade, pre-harvest payment for structurally disadvantaged small farmers and artisans, the development of long-term trading relationships, 
and transparency undergirded by independent third-party certification. Coffee was the first fair trade commodity, and while the system has since expanded to a wide variety of other products, it continues to be the most important in terms of volume and sales.

I make two principal arguments in this article. First, while fair trade has succeeded partially in "re-embedding" market exchange within systems of social and moral relations, it has also proved susceptible to the power of corporate actors who have sought to disembed the alternative through an increasingly successful process of cooptation. Second, I argue that such cooptation takes a unique form in the context of a social movement whose principal tools to achieve social change are certification and labeling: it occurs primarily on the terrain of standards, in the form of weakening or dilution.

Drawing from an extensive set of interviews with a range of players in the fair trade movement and market over the course of nine years (2001-2010), as well as document analysis and media coverage, this article describes fair trade's growing interaction with large mainstream trading and retailing firms over the movement's nearly 25-year history. I explore the intramovement tensions that have emerged over questions of tactics and strategy, particularly over the terms for and the effects of corporate participation. I also examine the case of transnational firms' involvement in the fair trade coffee market, focusing on two specific companies: the specialty-coffee giant Starbucks and the world's largest coffee trader, Nestlé.

In the following section, this article ties together several bodies of scholarship to gain theoretical purchase on the case of fair trade. I explore the influential notion of market embeddedness developed by Karl Polanyi (1944), bringing it together with both the social movements literature examining corporate campaigns and cooptation, and an interdisciplinary body of scholarship on certification, standards, private regulation, and the political economy of 
global commodity chains. A brief third section describes my research methods and data. The fourth part of the article focuses on the fair trade movement and market, charting their growth from a marginal, alternative civil society initiative in the late 1980s to an international certification system with sales of $\$ 5$ billion that has enrolled some of the largest transnational food traders and retailers (FLO 2009). Throughout, I utilize the concept of cooptation—a key analytic used by social movement scholars to understand the responses by states, as well as corporations, to social movement activity (Campbell 2001; Gamson 1968, 1975; Trumpy 2008) - to assess charges by movement activists that large firms have diluted fair trade standards and have used their often negligible participation to engage in "fair-washing" (Renard 2005). A fifth section steps back to assess the implications of this case study for social movement theory and for fair trade organizations, followed by some concluding observations.

\section{Perspectives on Movements and Markets}

\section{Market Embeddedness}

As neoliberal globalization has altered the balance of power between states, citizens, and capital by giving primacy to markets, many social scientists have found analytic utility in Karl Polanyi's (1944) historical critique of the "self-regulating" market. The advent of the market economy that accompanied the industrial revolution, argued Polanyi, led the production of goods to become "disembedded" from the systems of social and moral relations in which they had hitherto been grounded. The dire social and ecological consequences of this disembedding led eventually to the rise of "movements of self-protection" against the tyranny of the market, resulting in "a network of measures and policies [that] was integrated into powerful institutions designed to check the action of the market... [A] deep-seated movement sprang into being to resist the pernicious effects of a market-controlled economy" (1944: 76). The gains of this 
movement took concrete form in the $20^{\text {th }}$ century in welfare-state policies and in the increased regulation of capital. Ironically, it is the demise of this state-based regulatory project in the neoliberal era that has contributed to the recent resurgence of interest in Polanyi's work (Benería 1999; Block 1990; Guthman 2007; Turner 2007).

Several observers of fair trade have used this framework to examine the nature of the challenge that it poses to the dominant global market, evaluating fair trade's potential to "reembed" economic transactions in social relations (Fridell 2007b; Hudson and Hudson 2004; Jaffee 2007; Mutersbaugh 2005a; Raynolds 2000). Others characterize fair trade as a countermovement along the lines described by Polanyi (e.g., Fridell, Hudson, and Hudson 2008). However, the utility of this approach is complicated by the changing degree of embeddedness of the fair trade system. Analyzing the fair trade movement's complex and evolving relationship with corporate participants necessitates an examination of the dynamics of social movements that target corporations.

\section{Changing Targets and Tactics}

The sociological literature on social movements has over the last 15 years come to acknowledge that many SMOs no longer focus primarily, or even at all, on the state as the locus of their efforts to achieve social change (Van Dyke, Soule, and Taylor 2004). This shift is based on the recognition that in a neoliberal context, it is increasingly corporations, rather than the state, that are the dominant political and economic organizations in society. Several authors have argued that at least since the 1970's a combination of forces has challenged the power of national and local governments to regulate capital, including deindustrialization, economic globalization, and a new global trade regime, embodied in trade and investment agreements such as the North American Free Trade Agreement and supra-state bodies including the World Trade Organization 
(WTO) and more recently the G-20 (e.g., Harvey 2005; McMichael 1996). Pellow argues in an influential piece (2001: 47) that "the state's policy-making authority has weakened as corporations have become both policy makers and the new targets of challengers." ${ }^{1}$ These phenomena have caused a shift in the sociological literature on political opportunity structures. Since its appearance in the 1980s, this approach has emphasized the influence of exogenous factors - particularly the character of state institutions - on the effectiveness of social movements in achieving their demands, rather than stressing primarily internal dynamics (e.g., McAdam, McCarthy, and Zald 1996). However, the extension of neoliberalism has increasingly pushed scholarship on political opportunity structures away from a focus on the nature of governmental bodies and public policy, and toward a concern with characteristics and behaviors of both individual corporations and of industries, what Schurman (2004) refers to as industry structures. These structures, she argues, "are a critical determinant of movement efficacy when the primary target of opposition is corporations, rather than the state" (2004: 245). Concomitant with these changes in the targets of social movement contestation has been the development of a new repertoire of tactics, many of which can be subsumed under the broad rubric of the “corporate campaign.” Trumpy (2008), for example, examines a largely successful campaign by the environmental organization Greenpeace against Coca-Cola, using the corporation's participation in the Olympics to force it to take action to reduce its greenhouse gas emissions. Schurman $(2004 ; 2010)$ charts the rise of the international movement against geneticallymodified foods, linking its substantial success to astute campaigning strategies against highprofile corporations such as Monsanto. Seidman (2007) and Collins (2003), among others, trace the efforts by organized labor and human rights activists to take on stateless apparel firms with 
transnational organizing tactics, including independent monitoring of corporate codes of conduct in the subcontracted factories that make their branded clothes.

Although the increased focus on the characteristics of corporate firms and the tactics of social movements that target them is an important development, two dimensions directly related to industry structures have made only limited appearance in the literature on social movements. These elements can help to determine both the opportunities and the most effective tactics available to social change advocates, whether they are labor organizers in the global South or fair trade activists in the North. The first of these factors is the advent of product certification and labeling, a form of nonstate regulation which is increasingly being deployed by movements attempting to hold large firms accountable for the social and environmental effects of their practices, as well as by private industry and suprastate actors. The second dimension is the nature of the commodity chains that global firms utilize to harvest, produce, process, assemble, transport, package, and retail their products. Below I apply some of the key insights of the scholarship on private regulation, certification, and global commodity chains to the issue of the changing structure of opportunity for SMOs that focus on global corporations.

\section{Private Regulation, Standards, Certification, and Global Commodity Chains}

A broad range of scholars has charted the epochal changes generated by economic globalization (e.g., Harvey 2005; McMichael 1996; Sklair 2002). One of the subthemes of this literature is the rise of private governance, of which standards and certification are one manifestation. Busch and Bain (2004) discuss the growth of private standards, especially those created by retailing firms, which they claim now play a more significant role than either states or suprastate bodies such as the WTO in regulating and restructuring global markets. This move from public to private regulation parallels the retreat of the state from the regulation of markets 
under neoliberalism more generally. In terms of the organization of capitalist accumulation, it forms part of a broader shift from Fordism to "flexible accumulation" (Friedland 1994; Goodman and Watts 1994; McMichael 2007). Concomitant with all of these shifts are fundamental changes in the nature of the commodity chains for food and other products.

In this context, some observers argue that certification has emerged as a more politically palatable alternative to state regulation - a form Bartley characterizes as a distinct "mode of social regulation" (Forthcoming: 1). Certification responds to a range of imperatives from different actors, including consumers, who increasingly want reliable information regarding the attributes of products, and social movements, which "demand standards that can somehow regulate global supply chains" (Bartley Forthcoming: 9). Thus, the rise of private certification in the neoliberal era can be read as a response to "pressures to re-embed markets in social relations that have typically generated state regulation" (ibid.: 9) On the other hand, certification also responds to global firms' needs to rationalize far-flung production networks, protect their brands, and compete in the arena of corporate social responsibility. Bartley (2007b: 310 ) observes that the rules and "cultural scripts" of neoliberalism facilitate the rise of private regulation, as states are increasingly unable or unwilling to use formal regulatory power to control environmental and labor practices, particularly those of transnational firms. Therefore it is not surprising that most certification systems have been created by social movements or by NGOs, which he describes as “institutional entrepreneurs" in this arena.

The functioning of product certification has been conceptualized in various ways. According to Renard (2005), certification's power rests upon its ability to define not only specific qualities of goods or the social conditions they embody (e.g., production processes, labor conditions, or trading practices), but also to define which products do not meet such definitions. 
Such acts of delineation, she writes, "constitute, in effect, mechanisms of market entry and exclusion, converting them into a source of power for those who control them" (2005: 425).

The value claims that undergird product certifications are communicated to consumers primarily through labels or seals, and observers differ widely in their assessment of the limitations and possibilities of such markers. Barham (2002: 350) describes values-based labeling as a "manifestation of social resistance to the violation of broadly shared values" by the capitalist marketplace. Guthman, on the other hand, charges that voluntary product labels are "typical of neoliberal regulation" because they shift regulatory responsibility from the state to consumers: "not only do these labels concede the market as the locus of regulation ... but they employ tools designed to create markets" where none previously existed (2007: 457).

Yet there is a wide variety of product certifications currently in the marketplace, and to characterize them all as "neoliberal regulation" elides important distinctions between initiatives. First-party certifications are typically corporate self-policing systems with no intermediary involved (examples in the coffee sector include Starbucks' own "Café Practices" system, and "direct trade" claims made by various specialty roasters). Second-party certifications are usually created by an industry segment or association, rather than individual firms, but do not constitute independent verification. Third-party certifications are conducted, at least ostensibly, by independent, neutral bodies that engage in auditing and maintain a rigorous chain of custody to verify claims made by the firms they certify (fair trade certification and the Rainforest Alliance seal are both third-party systems).

A few high-profile cases of certification have received the bulk of academic attention. A coalition of social movements, NGOs, firms, and foundations created the Forest Stewardship Council in the 1990s in an effort to curb tropical deforestation (Bartley 2007a; Gulbrandsen 
2004; Klooster 2005; Taylor 2005b). Following widespread public outcry in the U.S. over sweatshop labor conditions in global apparel factories, leading firms were pushed to adopt voluntary codes of conduct. The Clinton administration worked with NGOs and firms to create the Fair Labor Association certification, and labor groups have engaged in independent labor monitoring to hold corporations accountable to their promises (Bartley 2007b; Collins 2003; Seidman 2008). Other initiatives are focused on the arena of agriculture and food (hitherto "agrifood"). Organic agriculture was the earliest of the current generation of certifications, and has generated a substantial body of literature (Allen and Kovach 2000; Guthman 2004; Rigby and Brown 2007). The Marine Stewardship Council was created to certify sustainably-caught seafood. Finally, the international fair trade system has drawn substantial scholarly attention as one of the earliest and largest certification schemes, as I discuss in the following section. In each of these cases - with the exception of organics ${ }^{2}$ - the third-party civil society initiative was eventually challenged by a newer, industry-sponsored, competing first- or second-party system.

If private standards, certification, and labeling are increasingly an important means of communicating claims regarding social and environmental conditions of production to consumers - whether based on civil society concerns for justice and sustainability, or on firms' desire for brand differentiation - then attention to the nature of the global production networks behind these goods is necessary. A substantial interdisciplinary body of literature, pioneered by Gereffi and Korzeniewicz (1994), examines the political economy of global commodity chains. The global commodity chain framework has been used extensively by scholars in the political economy of world-systems school, particularly those focusing on commodity chains in the agrifood arena (e.g., Friedmann 1994; McMichael 2000, 2007). One central focus of this work has been the nature of the restructuring of commodity chains under neoliberal or post-Fordist 
economic globalization. The key transformation in this arena has been the ongoing shift from "producer-driven" chains controlled by large production firms and characterized by mass-market products and vertical control, to "buyer-driven" chains in which quality is a key attribute, products are highly differentiated, and distributors or retailers (such as supermarket chains) are able to control producers, impose conditions, and capture an increasing share of value.

Additional work has contributed to further refining the typology of commodity chains. Gereffi, Humphrey and Sturgeon (2005) distinguish between "captive" chains, in which producers are tightly controlled by processors and/or retailers, and "relational" commodity chains, in which transactions are based on longer-term commercial relationships and the sharing of power and information across a network (Raynolds and Wilkinson 2007). The fair trade system is also premised on shortening the value chain by removing many intermediaries. The objective of the fair trade model at the outset was thus to create truly alternative commodity chains that would be both shorter and more relational—-thereby freeing up capital to be redistributed to farmers in the form of a higher, fairer price, and forging more direct links between producers and consumers (Raynolds 2002; Raynolds 2000). Yet as I describe later, the involvement of large corporate firms in the fair trade market has led to the certification of precisely the kind of longer, captive chains which the system was formed to counteract (Fridell 2007b; Renard 2003). The inclusion of these two fundamentally opposed types of economic exchange under a single seal has in turn set the stage for cooptation within fair trade.

\section{Cooptation}

The literature on social movement cooptation has traditionally viewed the state not only as the primary target of movement contestation, but as the agent of cooptation. Selznick's work (1948: 34) defined cooptation as "the process of absorbing new elements into the leadership or 
policy-determining structure of an organization as a means of averting a threat to its stability or existence." Gamson (1975) framed cooptation as an outcome in which a social movement or minority group becomes accepted by or is incorporated into the state apparatus (access), but does not achieve meaningful policy gains (new advantages).

This section poses two questions regarding cooptation. Is it appropriate to apply this concept - historically grounded in the study of movements aiming to change state policy and law - to a context in which corporations, and not the state, are the targets of social movement activism? And if so, how should cooptation be conceptualized in the case of groups whose challenges take place not in the form of corporate campaigning, but on the more narrow terrain of market-based strategies, specifically product certification?

Scholars have increasingly answered the first question in the affirmative, calling attention to the shift away from strong state regulation under neoliberalism, and the need for social movements to target corporations directly (Pellow 2001). ${ }^{3}$ Trumpy defines cooptation in this context as "a corporate target's ability to maintain SMO support without acquiescing to SMO demands" (2008: 480). Thompson and Coskuner-Balli (2007) examine the organic food movement in the U.S., arguing that its increasing corporatization is a form of cooptation. Trumpy's (2008) study of the campaign by the environmental group Greenpeace against Coca-Cola sheds useful light on these processes. In examining the effect of Greenpeace's efforts to force Coke to reduce its emissions of greenhouse gases that contribute to climate change, she distinguishes between three different possible outcomes: corporate reform, co-optation, and compromise, characterizing the outcome of that campaign as the latter. She highlights the dilemma confronting social movements that choose to adopt institutional strategies and tactics, which, in Gamson’s terms, stress acceptance over new advantages. “Overemphasizing 
acceptance," writes Trumpy, "distracts the SMO from its ultimate goals, such as changing corporate policies and actions ... movement actors are less likely to engage in protest that directly challenges a target's legitimacy or use other strategies that may counter cooptation by targets" (2008: 483). The "mainstreaming" strategy adopted by key leaders in the fair trade movement since 2000 - a choice to reach mass-market consumers by pursuing and certifying large corporate firms - is an example of such institutionalization.

The second question I posed above — how to understand cooptation within movements whose primary strategies and tactics involve market tools such as certification — has been far less well studied, although some scholars of certification provide the beginning of a response. Bartley writes that "engagement with certification may also carry dangers of co-optation and deradicalization" (Forthcoming: 16). He asserts that the development of Forest Stewardship Council certification resulted in major changes within the movement against tropical deforestation, shifting its primary focus away from protest and boycott tactics. Scholars studying the organic and sustainable agriculture movements (Allen and Kovach 2000; Campbell 2001; Guthman 2004; Howard 2009) have charted the progressive simplification and harmonization of organic food certification. Observers of anti-sweatshop movements have explored how the advent of corporate codes of conduct defused some of their radical potential (Fung, O'Rourke, and Sabel 2001; Klein 1999; Seidman 2008). Yet the latter case notwithstanding, competing (and typically lower-bar) corporate certifications and/or standards almost always appear after civil society-led initiatives are established. "Corporations," writes Bartley (2007b: 340), "are more likely to coopt forms created by others than to create them de novo."

Several sociologists examining the fair trade movement have suggested that the involvement of corporations holds the possibility of cooptation. Fridell, Hudson, and Hudson 
(2008) analyze what they term a "countermobilization" by the four largest coffee firms in response to the challenge posed by fair trade, applying Gamson's (1975) framework of movement outcomes. They conclude that the transnational firms' dominant approach has been to delegitimize fair trade, and that the outcome so far falls between "preemption" and movement “collapse." Jaffee $(2007 ; 2010)$ considers the potential for manipulation and cooptation of fair trade's core principles by large corporate entrants. Fridell (2007b: 287) explores the conundrum posed by corporate involvement, concluding that it risks "sacrificing the long-term feasibility of the movement for short-term gain." However, while this social science literature on fair trade has to varying degrees broached the topic of cooptation, it has yet to develop the concept as a central theme, to ground it in close empirical scrutiny of trends within fair trade, to tie it explicitly to the issue of standards, or to engage more substantively with the scholarly literature on social movement outcomes.

This piece extends upon the above contributions in several ways. It examines cooptation in fair trade as a central focus, drawing on both the literature on social movement outcomes and scholarship on private regulation and global commodity chains to compare fair trade with the aforementioned cases of cooptation in SMOs that have engaged corporate actors. It analyzes the phenomenon of cooptation through a close examination of the fair trade movement's historical trajectory, in particular the evolution of its relationship with corporate agrifood firms over the past decade, and the effect of that relationship on the policy choices made by key movement actors. Finally, this article makes two specific contributions regarding the nature of cooptation in social movements that engage with corporations primarily through labeling and certification. I argue that the most significant feature of cooptation for these movements is that it takes place specifically on the terrain of the standards underlying the certification itself. More specifically, 
the process of standards-related cooptation is best viewed through the lens of standards dilution or weakening. In my discussion below of the case study of the fair trade movement, I describe how the dilution of fair trade standards has generated substantial intra-movement conflict and has led to a significant degree of movement cooptation.

\section{Data and Methods}

This research project was designed as an extended ethnographic case study (Burawoy 1991). The data on which the analysis is based are drawn primarily from semi-structured interviews, and supplemented by three additional sources. I conducted interviews with a wide range of actors in the fair trade movement and market between 2001 and 2010, a period which encompasses nearly all of the history of certified fair trade in the U.S. and the most rapid growth of fair trade on an international level, as well as the entirety of the movement's engagement with transnational firms. During this time I attended many of the key conferences and fora on fair trade held in the U.S. and internationally. The interview respondents include the leaders, directors, board, staff and members of fair trade and allied NGOs, international certifiers and national fair trade licensing bodies located in the U.S., Europe, and Latin America, large and small coffee roasters and other firms, activist groups, and fair trade producer organizations, as well as researchers studying fair trade. Table 1 provides a breakdown of the respondents by organizational categories. I conducted interviews with 39 respondents; 35 were conducted in person and four by telephone. Of the 35 respondents representing fair trade organizations or retail firms, 23 were current or former directors and/or founders, and 12 were staff. Thirty of the interview subjects were male, and nine were female. The interviews lasted between 30 minutes and three hours, and were audio recorded. I initially assembled a core list of respondents from a small number of key informants; once interviews had begun I expanded the list through snowball 
Table 1: Categories and Organizations Represented by Interview Respondents

\begin{tabular}{|l|c|}
\hline Category/Organization & Number of Respondents \\
\hline Certifiers (3) & 2 \\
Fairtrade Labeling Organizations International (FLO)* & 1 \\
Certimex & \\
\hline Licensing Initiatives (5) & 2 \\
Transfair USA** & 1 \\
Fairtrade Foundation (UK) & 2 \\
Comercio Justo México & \\
\hline Fair Trade Retailers (9) & 7 \\
Coffee firms/roasters & 2 \\
Other firms & \\
& 2 \\
\hline NGO Staff/Representatives (13) & 6 \\
US & 4 \\
UK & 6 \\
Netherlands & 4 \\
Mexico & \\
\hline Producer/Farmer Organization Representatives & \\
\hline Fair Trade Researchers & \\
\hline
\end{tabular}

NOTE: All respondents (with the exception of researchers) are current or former directors, founders and/or staff of their respective organizations. The table does not sum exactly to the number of respondents $(\mathrm{N}=39)$ because one respondent had two overlapping roles.

* Name changed to Fair Trade International in 2010.

**Name changed to Fair Trade USA in 2010.

sampling. While not random, this sample is broadly representative of the range of key actors and perspectives within the fair trade movement and system. The interviews were conducted primarily at fair trade meetings and conferences, as well as in other locations arranged with respondents. While I quote only from a subset of the interviews in this article for reasons of length, the remainder of the interview data strongly inform the broader analysis. The choice of 
which interview respondents to include directly in the article was made with the aim of representing the founders, leaders, and staff of the key organizations that have been most influential in the national and international debates within the fair trade movement and system. The interviews were transcribed and coded to identify themes that emerged through analysis, and which later guided the organization of the article. These themes included the movement's history and founding principles; the relationship between certifiers and corporate firms; the effects of fair trade's growth, minimum price levels, and plantation production on standards and small producers; the role of different groups of fair trade retail firms; governance of fair trade institutions; and divergent understandings of the fair trade movement, market, and system.

The interviews were supplemented with comments and papers delivered by a range of fair trade actors at public meetings and conferences. I also made extensive use of media coverage of fair trade throughout the same period, taken from newspapers, magazines, and web sources. Finally, I drew on documents including annual reports, press releases, position statements and reports from certifiers, firms, NGOs, international institutions, and other sources.

\section{Trajectory of the Fair Trade Movement}

The fair trade movement emerged out of two distinct currents during the postwar period in both the U.S. and Europe (Jaffee 2007). One strand was rooted in liberal development groups and religious charities, such as Oxfam in the UK and SERRV in the U.S., which were focused on generating markets for the handicraft products of impoverished people and refugees through networks of "world shops." Another set of antecedents came from more radical solidarity activists and NGOs, who were oriented toward supporting grassroots movements in the Third World and particularly socialist states (Renard 1999a; Tiffen 2005). The multiple threads of this budding "alternative trade" movement slowly came together during the 1960s and 1970s, but not 
until the 1980s did the outlines of the current form of fair trade emerge. A co-founder of the first

U.S. fair trade coffee roaster, Equal Exchange, described the company's original vision:

We started meeting and talking about setting up a business...inspired by the Nicaraguan revolution, inspired by other development movements around the world... So we imported coffee from this group in Holland, and began selling to food coops and solidarity groups. This is at the height of the Nicaraguan solidarity movement, 1985.

...So that was really the origins, and we had never intended to be a coffee company-we thought we'd have a wide range of foods. And the original idea was really working with the social movements. (Rosenthal 2005)

A few years later, in 1988, came the step that established fair trade in its present form. The Dutch development NGO Solidaridad formed a partnership with the UCIRI indigenous coffee cooperative in Oaxaca, Mexico, with the goal of developing a bigger and more remunerative market for UCIRI's coffee. Solidaridad created a label-Max Havelaar — that could be affixed to any brand that met its criteria for fairness (Renard 1999b). These criteria were fourfold: payment of a firm floor or base price representing a "fair wage" for smallholders; pre-payment or credit to farmers in advance of the harvest, to avoid indebtedness; an additional premium payment to be used for social development projects; and long-term trading relationships with democraticallyorganized producer cooperatives or associations. As many alternative trade organizations and some smaller conventional roasters began using the Max Havelaar seal, the system slowly expanded to other nations, and eventually beyond coffee to other export crops, initially cocoa, bananas and tea. The structure was fairly simple: national licensing initiatives in each consumer country certified producer organizations to sell fair-trade products, and licensed firms that met fair trade criteria to use the seal on the products they purchased from those organized farmers. However, as fair trade grew throughout the 1990s, with licensing bodies eventually established in 17 European nations, this challenge to the conventional market underwent a gradual deradicalization. This was due in part to tensions present within fair trade's left-liberal 
coalition from the outset (helping to set the stage for cooptation), partly to the professionalization of fair trade organizations, and also in part to the adoption of a more formal, international certification model. A pioneering fair trade activist in the U.K. described these dynamics:

When Max Havelaar started, they were so connected and so motivated by what producers had to say, it was in the genes. It was in the DNA of the structure. ... [But] by the time it becomes a Euro-wide thing, that voice is being lost, because not everybody had that same ethos. But I think the more pernicious part of the story was the new wave of certification folks that were coming in at that time... with that came the notion that the closer you are to your beneficiaries, the less credible your mark is. ... So oddly enough, the growing-outof-adolescence-into-adulthood of this movement started to inject an argument or a logic that was the antithesis of what this was all for. (Tiffen 2005)

In 1997, faced with rapid growth, all of the European licensing initiatives created an international body to homogenize standards and administer certification: Fairtrade Labeling Organizations International (FLO), based in Bonn, Germany. Formal certification arrived in the United States fully a decade later than in Europe, and it quickly marked a major departure from the model developed there. The first U.S. fair-trade certified coffee was sold in 1998. While the new certification body, Transfair USA, ${ }^{4}$ was originally housed at the Institute for Agriculture and Trade Policy (IATP), a progressive Minneapolis-based think tank, it became independent in 1999 with substantial seed funding from the Ford Foundation, and moved to Oakland, California. Figure 1 shows the growth of fair trade coffee sales in the U.S., along with key events in the movement's history, which are described in greater detail below.

Transfair USA joined FLO and quickly adopted a concerted "mainstreaming" strategy to increase the volume of fair trade sales through conventional retail venues and under existing commercial brands, as opposed to the alternative trade groups that had dominated fair trade thus far. A founder of Equal Exchange coffee described this shift, which would prove to be a watershed in fair trade's development: 
What the fair trade labeling did is it took something that was a complete[ly] alternative economic chain called alternative trade - from producer all the way to the end consumer - and said, "well, in order to increase volume here, we're going to let go of the supply chain past the port of export, and as long as people source in this fair trade manner, we don't care what happens on this second half of the chain." And so, obviously, that opened it up to Starbucks, Green Mountain and anybody else who was willing to source according to that criteria. And so, volume has increased tenfold because of that, which is a tremendous accomplishment. (Rosenthal 2005)

\section{Figure 1: U.S. Fair Trade Certified Coffee Sales and Key Events in Fair Trade Movement and Market, 1986-2011}

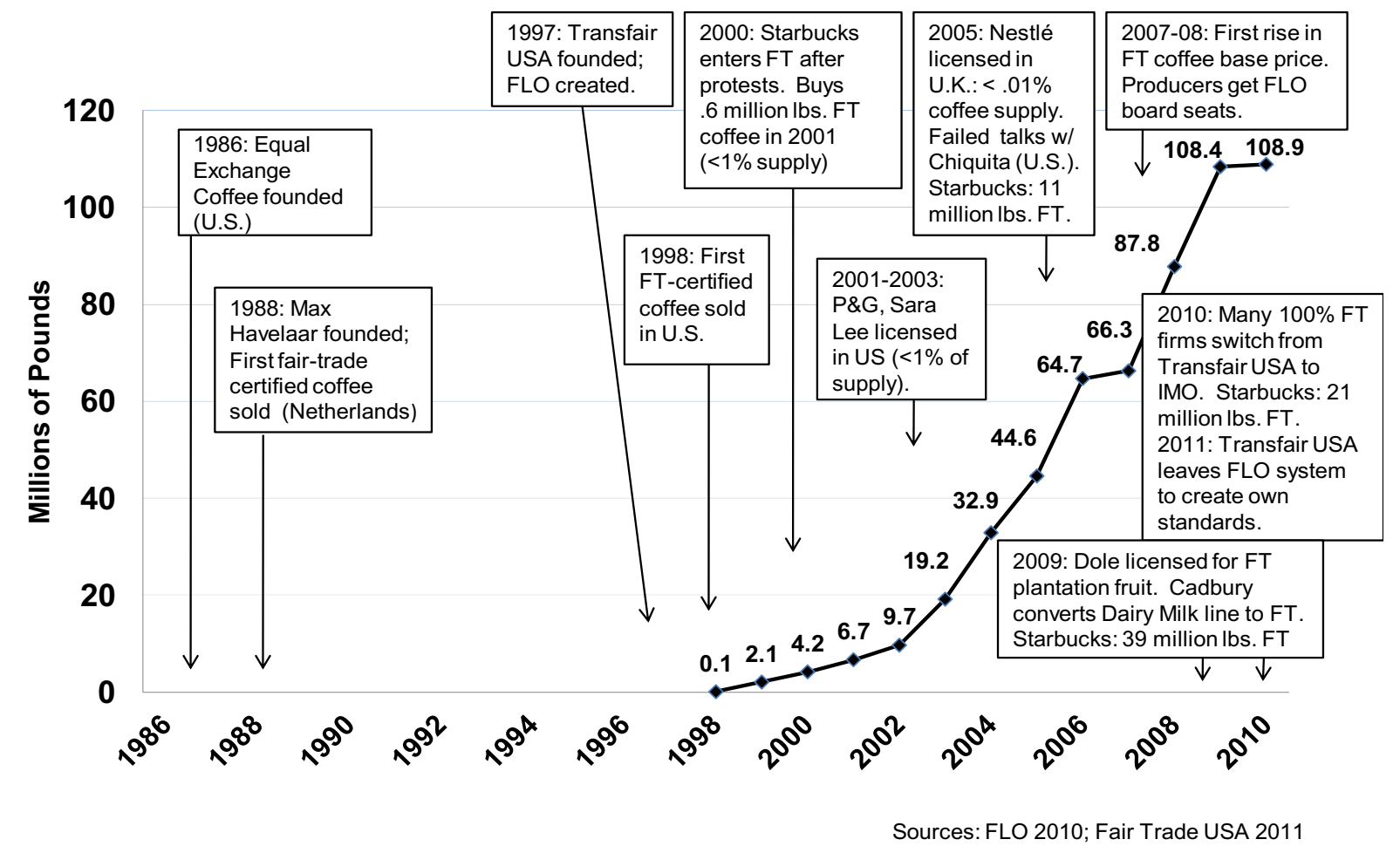

While the certification structure in the U.S. officially resembles that of the European licensing bodies, Transfair's relationship to the social movements from which it emerged is notably different. The European initiatives include formal representation from trade unions, development NGOs, and other groups. However, according to the Vice-Chair of FLO, 
There is a huge difference between Transfair USA's policies and the rest of the movement... I don't fully understand the Transfair USA model because it's not a membership, it doesn't have organizations belonging to it, so its own board decides who would be on there, and I think it's a relatively narrow spread of people, and views. And I can say for the discussion here, conservatively, that it lacks legitimacy. (Bretman 2010)

This lack of representation by social movements in the governance of Transfair would become a point of conflict shortly after it began to license companies to use the fair trade seal in the U.S., among the first of which was the specialty-coffee giant Starbucks.

Participants within the international fair trade movement hold a range of different perspectives regarding fair trade's role and the nature of the challenge it poses to conventional trade: a mechanism to access markets for disadvantaged producers, a tool to leverage corporate reform, or a vehicle for a more fundamental transformation of global trade (Jaffee 2007). Yet within the movement coalition, these philosophical and strategic distinctions were for many years largely ignored or blurred over, generating what Dorward (1974: 477) terms a "working misunderstanding," in which the parties simultaneously operate under distinct, even incompatible “conceptual models which had proven meaningful under quite different circumstances." This misunderstanding, as I describe later, extends to the semantic conflation of fair trade certification and licensing bodies with the social movement from which they emerged.

\section{Fair Trade Coffee: Transnational Firms and Intra-Movement Dynamics}

Fair trade was founded during an era of regulated coffee trade, under the International Coffee Agreement quota system that had functioned as a price and supply stabilizer since the early 1960s. However, it soon came to represent an alternative to the harmful effects of a liberalized coffee market, which sowed the seeds of its eventual focus on corporate firms. When in 1989 the Agreement collapsed, due in part to U.S. commercial and foreign policy interests, the market was glutted and world coffee prices crashed, jeopardizing the livelihoods of 20 to 25 
million farmer families, wreaking social and environmental damage, and dramatically reducing producing countries' share of the coffee dollar (Oxfam America 2002; Talbot 2004). Figure 2 portrays the movement of both conventional and fair trade coffee prices since 1989. Economic

Figure 2: Conventional and Fair Trade Minimum Arabica Coffee Prices (Nominal), 1988-2010

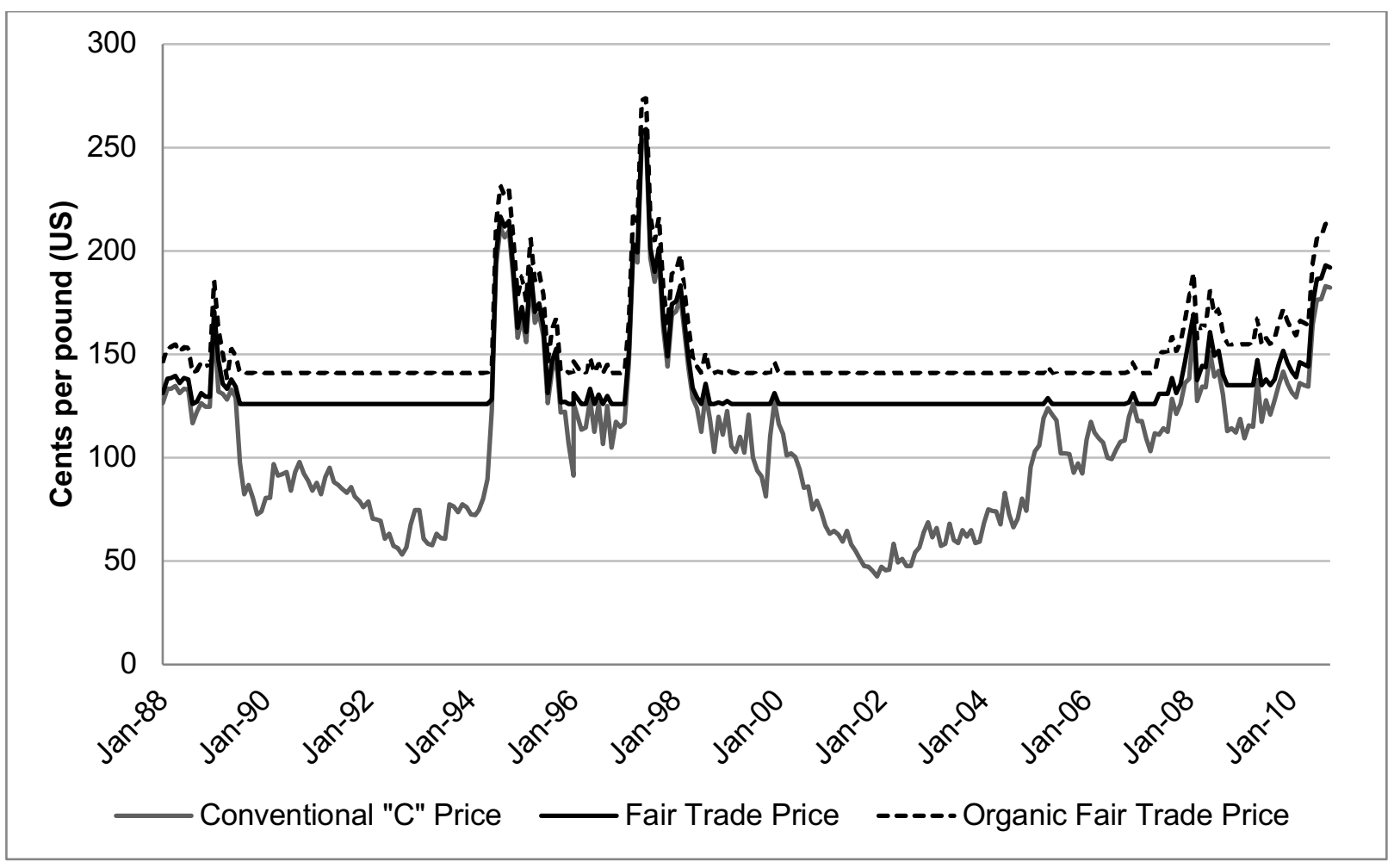

Sources: ICE Futures 2010; FLO 2010

power in the coffee industry is highly concentrated, with the "Big Five" transnationals—Nestlé, Kraft, Procter \& Gamble, Sara Lee and Tchibo - controlling 69 percent of global roasted and ground coffee sales (Ponte 2002). These traders reaped billions in additional profits during the 1989-1994 period, and again during the more recent and severe price crash, which lasted from 1999 to 2005 (Charveriat 2001; Oxfam International 2004). During these twin crises, as Figure 2 indicates, fair trade's minimum or base prices paid to producer organizations for green 
(unroasted) coffee- $\$ 1.26$ per pound, and $\$ 1.41$ for certified organic coffee-were well above the world price, as much as three times higher.

In 2000, during the most recent price crash, the U.S. fair trade movement began to focus on transnational coffee firms, a move that offered a window into the shifting relationship between SMOs, firms, and Transfair USA. Global Exchange, an established human rights NGO, chose to target Starbucks, which was the largest specialty coffee roaster, although at the time still quite small in comparison with the Big Five. After agreeing to Global Exchange's demand to buy fair trade coffee, Starbucks entered into negotiations with Transfair USA, the new U.S. licensing initiative. The two announced that Starbucks would make fair-trade coffee available in both whole-bean and brewed form at all of its U.S. stores, although the volume was left undefined (Starbucks and Transfair USA 2000). In 2001, Starbucks purchased 653,000 pounds of certified coffee, and promised to buy one million pounds the following year (Starbucks 2001), well below one percent of its overall supply. These developments, while a breakthrough for the movement's visibility, generated angry responses from several long-time roasters who sold exclusively fair trade coffee. They argued that the agreement violated norms that had required a minimum of five percent of a firm's supply to be purchased at fair-trade terms in order to have the right to use the seal, and that it did not require Starbucks to increase its purchases over time:

Transfair ...purposely sidestepped the question of volume, of percentage commitment, in signing these guys up. They've got to do that. We've got to keep them working. There has to be percentage advances every year, or else they should be penalized (Earley 2004)

After Starbucks entered the fair trade market, several dozen regional and national specialty-coffee roasters, such as Green Mountain and Peet's, followed suit. Separately, a number of mass-market coffee firms, including Procter \& Gamble and Sara Lee, were licensed by Transfair USA, but their sales volumes remained negligible. ${ }^{5}$ There was growing recognition 
among movement activists that transnational firms brought a distinct set of motivations to their engagement with fair trade:

You have companies like a Green Mountain or a Starbucks, or certainly Procter \& Gamble, where many of them were kind of forced into doing fair trade, and so some of them are trying to see how little can we do and not get attacked; some of them are looking at, "well this can be a part of our social responsibility." (Rosenthal 2005)

In that same year, the licensing initiative in the U.K., the Fairtrade Foundation, announced that Nestlé — the world's largest coffee trader and largest food corporation — would receive the fair trade seal for a small line of coffee titled Partner's Blend. The Foundation acknowledged that certifying the corporation, for two decades a target of consumer boycotts over its infant formula marketing practices, would antagonize many movement activists. A Global Exchange campaigner summed up the concerns of NGOs that allowing Nestle to use the seal "would make a mockery of the entire fair trade label, and [contradict] our history of resistance against the company for any number of other policies" (Guzzi 2005). Yet by 2008, fair trade still represented only 0.0025 percent of Nestlé's total coffee volume (Tropical Commodity Coalition 2009). While Nestlé had promised to increase fair trade sales volumes over time, the Fairtrade Foundation's deputy director acknowledged in 2010 that the firm had so far failed to do so: "we have got an agreement about continued increase, we've got targets, [but] they're not legally enforceable" (Bretman 2010).

The greatest concern expressed by fair trade movement groups and many 100 percent fair trade companies is that without binding commitments to volume growth, large firms can utilize the fair trade seal to burnish their corporate images and mislead consumers about their overall business practices, without meaningfully altering those practices. The potential of the fair trade label to serve as a vehicle for "fair-washing" (Renard 2005) in the fast-growing arena of corporate social responsibility claims is acknowledged by the licensing bodies. "I have no 
blinders on about what these companies have done," remarked the CEO of Transfair USA. "I just feel that if they're willing to step up and reinvent themselves in real concrete terms, not in a token way, but in a significant way that's going to affect the lives of tens or maybe even hundreds of thousands of workers, then that's something I want to be open to ...[But] we don't want to be a PR device, or a greenwashing device, for anyone" (Rice 2005).

This issue, among others, has highlighted the distinctions between two groups of fair trade retailers: on one hand a "mission-driven" group of small and medium companies, most of whom sell 100 percent fair trade products, and on the other hand corporate firms attracted by fair trade's profitability as a small niche market. This division has emerged as the key source of intra-movement tensions, particularly around specific tactical and strategic choices made by the licensing initiatives (Jaffee 2007). A co-founder of Equal Exchange voiced these concerns:

There are ways that the 100-percenters, the high-roaders, the mission-driven, whatever we call them, could have been used to incentivize, and provoke, and stimulate and motivate the corporate folks. But instead it's become an either-or game. And the 100percenters have felt used, basically. This corporate volume has been built on their backs, and they were disposable. (Rosenthal 2005)

Because labeling is the key means of communicating fair trade claims, conferring the right to use the seal grants firms access to valuable branding real estate; for this reason, activists and mission-driven retailers argue that it should be conditioned upon meeting a high, and rising, bar.

This controversy over corporate "dabblers" participating in fair trade at allegedly token levels reflects a deeper divergence between the competing models of social change within the movement. The president of Cooperative Coffees, a coalition of 100-percent fair trade roasters, framed the issue as one of the integrity of fair trade standards:

There's some reasons that 100 percent fair traders ought to get behind these companies moving in, but we've got to understand what principles and regulations and rules [will apply], but we shouldn't be looking at lowering standards in order to let them in...we 
should if anything use that as an opportunity to lift it, not come down closer to their normal standards. (Harris 2005)

In addition to the contention over where to set the bar for corporate participation, two other policy issues have generated substantial controversy. The first of these is the level of the minimum prices for certified goods, particularly coffee. FLO sets the levels of the minimum prices and the development premium for each commodity, which are the key redistributive mechanisms in the system and constitute an integral part of fair trade standards. The coffee floor prices were established in 1988 based on studies of production and living costs for farmer households. However, they were never tied to inflation and remained virtually unchanged for 20 years, rapidly losing purchasing power. By 2008—even after FLO acceded to strong producer pressure and raised coffee prices marginally ${ }^{6}$ - the base price had fallen by 41 percent in real terms, and would have needed to be $\$ 2.29$ per pound to keep pace with inflation (Bacon 2010). Calo and Wise (2005: 40) assert that in Mexico, the fair trade price had lost 75 percent of its real value by 2005 . These stagnating price levels reflected a political stalemate between the interests of the larger commercial players in the certification system, and producer organizations' desires to keep pace with rising costs. Since the recent price crisis ended in 2005, coffee producer organizations have increasingly complained that even for those groups able to sell all of their export-grade coffee at fair trade prices, many of their members could not cover their costs of production (Bacon 2010; Jaffee 2007). In 2011, however, faced with a dramatically higher world coffee market, FLO was obligated to raise prices and premiums in order to keep competitive with conventional intermediaries. As of this writing, the effective fair-trade base prices are $\$ 1.60$ per pound for conventional coffee and $\$ 1.90$ for organic (FLO 2011a).

The second point of conflict involves the extension of fair trade standards and certification into an entirely new arena: waged laborers in plantation agriculture. The "hired 
labor modality" was originally intended as a minor adjunct for crops such as tea and bananas, which are produced both on estates and by smallholders, but where a reliable supply from the latter was not always available. Increasingly since 2003, however, FLO and Transfair USA have expanded the range of products produced by agribusiness plantations, arguing that this represents an opportunity to change the behavior of large firms with historical reputations as "bad actors" (Frundt 2009; Goigoi 2008). Certification of waged labor enterprises is based on a distinct set of criteria from the original small producer mode: employers must pay national minimum wages, workers have the right to organize (but the presence of independent unions is not guaranteed), and fair trade premiums are placed in a fund to be administered by a management-labor "joint body" for projects benefiting workers (Bahra 2009; Goigoi 2008). The bulk of the growth in global fair trade sales now comes from the agricultural plantation sector, which as of 2010 included 185 certified large enterprises employing a total of 128,000 workers (Raynolds 2010). Fair trade cut flowers, fresh and dried fruit, tea, sugar, cotton, and spices, among other products, are sourced largely or entirely from plantations and estates. In 2009, Transfair licensed Dole, the top transnational banana producer, to place the fair trade seal on bananas and pineapples produced on plantations in Ecuador (The Packer 2009). These developments are due in large part to the demand of retail grocery chains such as Whole Foods, Sam's Club and Carrefourexemplars of buyer-driven commodity chains - for an increasing variety and volume of certified products (Conroy 2010). However, recent media coverage of fair trade plantations has reported allegations that some workers on certified estates are paid below national minimum wages, that Transfair and Fairtrade Labeling Organizations are unable to monitor labor conditions effectively, that the joint bodies are controlled by management, and that unionization is virtually nonexistent (Bahra 2009; Goigoi 2008; International Labor Rights Forum 2010). 
In contrast with independent labor monitoring of factory conditions by NGOs in the apparel sector, the expansion of agrifood fair trade certification into waged labor has been driven not by labor unions or other movement groups, but primarily by the demands of retailers, although international unions were involved in earlier efforts to develop fair-trade bananas (Frundt 2009). Indeed, a key labor rights NGO expressed serious concern about FLO's recent revision of its standards for hired labor. The revised standards, the group alleges,

would weaken enforcement, place more control into the hands of employers and would likely result in worse conditions for workers ... The proposed changes appear to be deliberately weakening protections for workers in order to allow more employers into the system who do not currently respect workers. (International Labor Rights Forum 2010)

The push by FLO to expand plantation agriculture soon generated substantial opposition from organizations of small coffee producers. "There was a struggle [over] whether we're going to bring in plantations in coffee," said an Equal Exchange co-founder. "Well, we kind of won that one, at least...but it will take a very significant amount of organizing to have a chance to stop the lowering of standards. (Dickinson 2004)

As a result of substantial lobbying within FLO by farmer groups and fair trade NGOs, four fair trade certified commodities—cocoa, coffee, honey, and cotton—remain for the moment limited to smallholder production only. However, in September 2011, Transfair USA generated major controversy by announcing that it would leave the FLO system entirely, in order to create new independent standards that will permit unlimited certification of plantation-produced coffee and other crops (FLO 2011b). This could permit large roasters such as Starbucks to become 100 percent fair-trade certified without altering their supply chains.

The strategy of market mainstreaming adopted by FLO and the licensing initiatives has proven quite effective at expanding both the supply of and demand for fair trade goods. Sales have continued to rise despite the recession, and the global market for all certified fair trade 
goods surpassed $\$ 5$ billion in 2010. FLO has developed standards and prices for almost 200 products, and retailers sell over 27,000 items containing fair trade ingredients (Bretman 2010; FLO 2010). ${ }^{7}$ Several major companies in Europe, including Cadbury and Sainsbury's, have substantially increased fair trade purchases of cocoa and fresh fruit (Tranchell 2010; Vidal 2007). Coffee remains the biggest fair-trade product, with U.S. sales reaching 108 million pounds in 2009 and in 2010, as Figure 1 indicates (Fair Trade USA 2011). A significant proportion of this growth was due to purchases by large firms. While Nestlé and J.M. Smuckers continue to buy only token quantities, Starbucks' fair trade coffee purchases had risen by 2009 to 39 million pounds, making it the largest buyer of certified beans worldwide (Starbucks 2010).

For many of the mission-driven companies, on the other hand, the mainstreaming strategy has proven more problematic. An indicator of their disaffection is the fact that by 2010 , the majority of the 100-percent fair trade retailers in the U.S. had left the FLO/Transfair system, with many of these shifting to a new certification system, "Fair for Life," established by the organic certifier IMO (Equal Exchange 2010). Looking toward the future, the movementaligned fair trade companies express a mix of appreciation for the benefits generated by fair trade's growth and apprehension about the effects of transnational firms' entry into the system. "We've forced multinationals to start playing this game to some extent," argued Equal Exchange's co-founder. "I'm proud of that. On the other hand, when I see what the impact of the multinationals is going to be, and when I see how the social movement in the US that now does kind of follow fair trade in some way, how they are indirectly being influenced by multinationals' agendas, that's pretty disconcerting" (Dickinson 2004).

After having explored the fair trade movement's trajectory and its growing interaction with large corporate firms, in the following section I assess the implications of this case study, 
both in terms of the nature and degree of social movement cooptation, and the challenges facing

SMOs that utilize certification as a primary tool to effect social change.

\section{Assessing Cooptation, Standards Dilution, and Movement Responses}

Trumpy defines cooptation as "the ability of a corporate target to bring the interests of a challenging group into alignment with its own goals" (2008: 480). Corporate firms can employ a range of approaches to defuse the threats that regulation-even in the form of private, voluntary product certification - would represent to their commercial practices and profit margins, if based on high standards and rigorously enforced. Analyzing these strategies can offer useful insights into the nature of social movement cooptation in the certification realm. Firms that choose to engage with such regulatory regimes have a structural interest in rewriting the "rules of the game" in ways that allow them to maximize the public-relations benefits of the seal, but permit them to continue existing sourcing, labor, pricing, distribution, and retailing practices, and to maintain or increase profit margins. Thus, pressure from corporate participants to lower the standards bar should be expected. "Firms typically prefer weaker commitments with minimal enforcement,” writes Bartley (2007b: 311), “while social movements prefer stronger, binding standards." The relevant question, then, is whether the regulatory body is capable of withstanding such pressures and maintaining high standards, forcing firms to make real changes that advance key movement principles. "Gaining new advantages," writes Trumpy (2008: 488), is what distinguishes cooptation from corporate reform or compromise. In the former outcome, the formal authority retains the power and is able to dissolve its relationship with the co-opted party at anytime, and presumably will do so as soon as this partnership is no longer in its interest. In the latter outcomes, the challenging group is able to acquire some of this power and has actual influence over the formal authority.

Do FLO and the licensing initiatives have "actual influence" over the corporations they

license, have those firms instead rendered the regulatory mechanism toothless (Fridell, Hudson, 
and Hudson 2008; Renard 2003), or does the outcome lie somewhere between these two poles? A brief review of two key fair trade policy developments is helpful in assessing which description is most accurate. The minimum purchase level required for firms' entry into the system was among the earliest points of contention. The deal between Starbucks and Transfair USA effectively set this bar to entry at less than one percent of supply; other large roasters followed the company's lead, but entered at even lower volumes. The biggest of these transnationals—including Nestlé and J.M. Smuckers—remain well below one percent several years later. A second instance is the growth of the hired labor segment of the market, involving a substantial increase in certification of plantations. The move to increase lenience and flexibility for employers under these standards, labor advocates argue, speak to the strong pressure on FLO from retailers to qualify more agribusiness growers for the fair trade seal. Yet fair trade officials contest that interpretation. "The notion that the standards have been lowered is ill-informed," says the CEO of Transfair USA. "Our objective is to help the poor, whether they own a plot of land or not" (quoted in Goigoi 2008). However, Transfair USA's 2011 decision to break from the FLO system entirely and open certification to all plantation products appears to lend further credibility to the charges of standards weakening by producer and labor groups. The expansion of hired labor production is seen as a positive development by those participants with a more reformist orientation, because companies are required to adhere to marginally higher standardsalthough these often simply entail respecting, rather than flouting, national labor laws. Those fair trade participants invested in a more transformational model of fair trade, on the other hand, see these developments as problematic, arguing that such engagement "can go a long way to polishing even the worst corporate image" (North 2008). 
Taken together, the outcomes of the various controversies in the fair trade policy arena can best be characterized as a dilution of standards. The agents of this dilution are both the large firms exerting pressure to modify the standards, and the certification and licensing bodies that have often acceded to this pressure. While there are some elements of compromise (such as the issue of minimum price levels), in most areas the clear trend is toward a lowering of the bar, permitting the inclusion of actors, production forms, and commercial practices that would have been non-conforming under previous versions of the standards. This indicates that corporate firms have largely succeeded in bringing the interests of fair trade certification leaders "into alignment" with their goals (Trumpy 2008: 480). In the realm of tactics, the certifier and the licensing bodies have clearly favored institutional approaches, stressing access and negotiation over maintaining a high bar for entry - a phenomenon especially pronounced in the U.S. case. Evaluating whether fair trade has achieved new advantages, of course, hinges on the definition of such advantages. FLO and Transfair have defined volume growth as the key metric of success, but if new advantages are understood to entail "actual control" over corporate firms, as Trumpy insists, then it is reasonable to conclude that FLO and Transfair have not achieved such control.

A related issue is the question of who or what constitutes the fair trade movement, and who speaks or acts on its behalf. As the market has grown, there has been an increasing semantic conflation of fair trade SMOs with the certification and licensing bodies and the seal itself - that is, the fair trade system. While the difference between movement and system is clearly important, it has become blurred. ${ }^{8}$ FLO and the national licensing initiatives have gained substantial power as the system has grown through its embrace of institutional approaches, conventional market actors, and agribusiness production. To date, social movement groups have failed to voice a clear alternative posture or mount a coherent challenge to these policies from 
within the system. "If a movement's leaders are largely autonomous," argues Trumpy (2008: 483), "leaders are able to control the organization without the consensus of rank and file members." While the governance structures of the licensing initiatives in most countries are fairly representative of the range of constituencies within their respective fair trade movements, thus reducing their freedom to act autonomously, Transfair USA is a notable exception. The founder of a movement-aligned coffee roaster that left the certification system argued that the US licensing body is "not the movement, and I think that somewhere along the line, folks at Transfair, and folks outside Transfair, sort of forgot that" (Earley 2004).

This "working misunderstanding"- a glossing-over of the distinction between the certification system and the movement itself — has arguably facilitated cooptation, as Transfair and FLO have been able establish precedents for corporate participation that will be difficult for the mission-oriented groups to reverse. "Our experience in the U.S.," said a co-founder of Equal Exchange, "was that the [fair trade] brand was handed over, but somehow there was no accountability built in back to these original folks or the movement...Somehow we lost power, we lost the accountability of our brand" (Rosenthal 2010).

These tensions between what some activists term the "deep" and "shallow" approaches to fair trade also illustrate the importance of the nature of the commodity chains that social movements aim to regulate. The trading chains within the fair trade system have shifted since its inception from shorter, alternative or "relational" linkages characterized by smallholder agriculture, long-term commercial relationships and movement-oriented retailers, toward longer, conventional or "captive" chains marked by vertically integrated transnational firms, waged labor, and agribusiness plantations, and also toward the "buyer-driven" chains controlled by retailers (Brown and Getz 2008; Mutersbaugh 2005a; Raynolds and Wilkinson 2007). This 
dynamic also reflects the increasing power of large firms, rather than SMOs, to influence the direction of the fair trade system, a phenomenon Mutersbaugh (2005a: 2035) describes as a "corporate social movement" against the restrictions to capital posed by stringent standards. By prioritizing access over new advantages_or by redefining "new advantages" as merely an increase in sales - the most powerful actors in the fair trade system have achieved dramatic success in terms of growth, but at the cost of rendering fair trade primarily an adjunct to the conventional market, rather than posing a fundamental challenge to the terms on which it operates. For social movements whose principal tool for effecting social change is voluntary certification, then, cooptation is most likely to occur in the arena of the effectiveness, integrity, and/or rigor of standards. And the form that cooptation takes is likely to be the dilution of the content of those standards, upon which the certification rests.

Some observers have characterized certification (and certification-like approaches such as independent labor monitoring) as a force for greater corporate accountability because it offers firms a more palatable alternative to tactics such as boycotts or "naming and shaming" approaches (Bartley 2007b; Fung, O'Rourke, and Sabel 2001; Seidman 2007). However, fair trade groups have only employed such confrontational tactics in a very few instances, notably the Starbucks case, and this approach has largely been abandoned in favor of negotiation between certifiers and corporations, leaving SMOs largely on the sidelines. Yet some scholars observe that without the "stick" of confrontational tactics, the "carrot" of certification has proven ineffectual in transforming corporate practices (Fridell, Hudson, and Hudson 2008; Jaffee 2007). By empowering professional certifiers rather than SMOs to establish and negotiate the content of standards, the use of certification as a primary social movement tactic increases the potential for cooptation and dilution, in the absence of strong safeguards. It is also likely to alter social 
movement ecology, as it has in the case of fair trade, by shifting power away from activists to administrators and firms - that is, from the movement to the system and the market.

\section{Conclusions}

In this article, I have made two main arguments regarding the nature of cooptation in social movements that engage with corporations primarily through the tactics of labeling and certification. First, for SMOs that employ certification as the principal tool in their efforts to effect social change, the central feature of cooptation is that it occurs primarily on the terrain of the standards undergirding certification. Second, this analysis of the case of the fair trade movement illustrates the unique shape taken by cooptation in the context of voluntary product certification: dilution or weakening of the standards on which the certification is based, allowing previously non-complying firms and behaviors to qualify.

This article has extended upon previous scholarship on social movement outcomes by linking it to the literatures on private regulation, certification, and global commodity chains, as well as market embeddedness. I have contrasted fair trade with other cases of cooptation in social movement that have engaged corporate actors, drawing a key distinction between SMOs that employ corporate campaigning tactics (such as movements opposing genetically modified foods or firms' contributions to climate change) and those using market-centered approaches. For social movement theory, these insights demonstrate the need for greater conceptual clarity regarding the ways that movements utilize (and are transformed by the use of) tactics such as voluntary product certification. They argue for a broader understanding of the specific processes and tactics by which corporations are able to coopt SMOs' transformative potential on this relatively new and highly contested terrain. The case of fair trade also demonstrates the need to consider two less-theorized elements of industry structures — the nature of firms' global 
commodity chains, and the use of nonstate regulatory forms such as product certification — in analyzing the opportunities and constraints facing social movements that focus on corporations.

Conversely, the article departs from previous scholarship on certification and standards by focusing upon cooptation as a central theme, and by grounding this study in an empirical examination of the fair trade movement's changing relationship with corporate agrifood firms over the past decade, which is reflected in the shifting content of standards. Certification is sometimes framed as an adjunct to corporate campaigns, providing a "carrot" to accompany the "stick" of boycotts and protests in sectors marked by social and environmental abuses (Seidman 2007; Taylor 2005a). Close attention to the nature of these standards and how they change over time - their form, specific content, consistency, rigor, degree of autonomy, governance structures, and enforcement - is important for understanding the dynamics of cooptation in such contexts. What may appear as intra-movement policy debates over the content of standards, for example, may instead be the actual process of cooptation unfolding.

For fair trade activists, the blurred identity of fair trade as both social movement and certification system illustrates the major challenges facing SMOs that operate primarily in this arena. The conflation of the certification system with the entire movement has allowed FLO and licensing initiatives such as Transfair USA to speak and act for that movement. This is possible because of their size and power relative to movement NGOs, as well as their ability to create "facts on the ground" by licensing large corporate firms at terms that create a low bar to entry. Under such circumstances, the semantic and practical significance of the fair trade label becomes challenging to pin down. Presently, transnationals can receive fair trade certification for their own captive, often vertically-integrated supply chains, without making substantive changes to them. Aside from stipulating payment of a base price to farmers or the minimum wage to 
laborers, certifying such chains does not render them meaningfully more relational or socially embedded, while it further disembeds the seal itself. At the same time, this analysis also suggests a potential outline of routes for those actors who seek to reassert the original transformative character of the movement from within. The recent creation of the Fair World Project, an NGO founded by Global Exchange and the Organic Consumers Association to organize consumers to protect and restore the integrity of fair trade (and organic) standards, is an intriguing move in this direction (Fair World Project 2010).

On a broader level, the fair trade case demonstrates that private regulation by civil society groups and SMOs — via tools such as certification and standards - is an approach fraught with serious limitations. Because of the voluntary nature of these market mechanisms and the lack of safeguards against token participation, they are susceptible to cooptation and dilution by the large economic interests whose behavior they are designed to reign in. More generally, it highlights the substantial problems with the use of market-based mechanisms as a path to reembedding international economic exchange into a framework of moral and social relations as envisioned by Polanyi. Indeed, the fair trade case can be read as a cautionary tale about the limits of voluntary, nonstate regulation, and the risks for social movements of embracing the narrower, less accountable realm of the market as the locus of change. It indicates the need for SMOs to consider alternative frameworks for re-regulation of global corporations, for example incorporating binding minimum social and environmental standards into international trade agreements or other suprastate institutions. Taking such a route would, perhaps ironically, entail social movements turning their efforts back to the state after all. 


\section{REFERENCES}

Allen, Patricia and Martin Kovach. 2000. "The Capitalist Composition of Organic: The Potential of Markets in Fulfilling the Promise of Organic Agriculture." Agriculture and Human Values 17:221-232.

Bacon, Christopher. 2010. "Who Decides What is Fair in Fair Trade? The Agri-environmental Governance of Standards, Access, and Price." Journal of Peasant Studies 37:111-147.

Bahra, Parminder. 2009. "Tea Workers Still Waiting to Reap Fairtrade Benefits." The Times (UK), January 8.

Bandy, Joe. 2004. "Paradoxes of Transnational Civil Societies Under Neoliberalism: The Coalition for Justice in the Maquiladoras." Social Problems 51:410-341.

Barham, Elizabeth. 2002. "Towards a Theory of Values-Based Labeling." Agriculture and Human Values 19:349-360.

Bartley, Tim. 2007a. "How Foundations Shape Social Movements: The Construction of an Organizational Field and the Rise of Forest Certification." Social Problems 54:229-255.

—. 2007b. "Institutional Emergence in an Era of Globalization: The Rise of Transnational Private Regulation of Labor and Environmental Conditions." American Journal of Sociology 113:297-351.

—. Forthcoming. "Certification as a Mode of Social Regulation." in Handbook of the Politics of Regulation, edited by D. Levi-Faur.

Benería, Lourdes. 1999. "Globalization, Gender and the Davos Man." Feminist Economics 5:6183.

Block, Fred. 1990. Postindustrial Possibilities: A Critique of Economic Discourse. Berkeley, California: University of California Press. 
Bretman, Ian. 2010. Board Vice-Chair, FLO; Deputy Director, Fairtrade Foundation. Personal Communication. Boston, MA, September 12.

Brown, Michael Barratt. 1993. Fair Trade: Reform and Realities in the International Trading System. London: Zed.

Brown, Sandy and Christy Getz. 2008. "Privatizing Farm Worker Justice: Regulating Labor Through Voluntary Certification and Labeling." Geoforum 39:1184-1196.

Burawoy, Michael. 1991. Ethnography Unbound: Power and Resistance in the Modern Metropolis. Berkeley: University of California Press.

Busch, Lawrence and Carmen Bain. 2004. "New! Improved? The Transformation of the Global Agrifood System." Rural Sociology 69:321-346.

Calo, Muriel and Timothy A. Wise. 2005. "Revaluing Peasant Coffee Production: Organic and Fair Trade Markets in Mexico." Global Development and Environment Institute, Tufts University, Somerville, MA.

Campbell, David. 2001. "Conviction Seeking Efficacy: Sustainable Agriculture and the Politics of Co-optation." Agriculture and Human Values 18:353-363.

Charveriat, Celine. 2001. "Bitter Coffee: How the Poor Are Paying for the Slump in Coffee Prices." Oxfam Great Britain, London.

Collins, Jane. 2003. Threads: Gender, Labor, and Power in the Global Apparel Industry. Chicago: University of Chicago Press.

Conroy, Michael E. 2010. "Social and Environmental Certification Systems in Latin America: Reach, Impact, and Challenges." Paper Presented at Latin American Studies Association (LASA) Congress, Toronto, Canada, October 6-9, 2010. 
Dickinson, Rink. 2004. Co-Director, Equal Exchange Coffee. Personal Communication. Canton, MA, May 25.

Dorward. 1974. "Ethnography and Administration: A Study of Anglo-Tiv 'Working Misunderstanding'." Journal of African History 15:457-477.

DuPuis, Melanie and Sean Gillon. 2009. "Alternative Modes of Governance: Organic as Civic Engagement." Agriculture and Human Values 26:43-56.

Earley, Matt. 2004. Co-owner, Just Coffee. Personal Communication. Madison, WI, May 6. Equal Exchange. 2010. "Why is Equal Exchange Now Using Institute for Marketecology (IMO) for Most of Our Products?" Retrieved October 15, 2010 (http://www.equalexchange.coop/why-is-equal-exchange-now-using-institute-formarketecology-imo-for-most-of-our-products-).

Fair Trade USA. 2011. "2010 Almanac." Fair Trade USA (Transfair USA), Oakland, CA. Fair World Project. 2010. "Fair World Project: Fair Trade for a Better World." Retrieved December 5, 2010 (http://www.fairworldproject.org/).

FLO. 2009. "Fairtrade Leading the Way: Fairtrade Labeling Organizations International Annual Report 2008-09." FLO, Bonn, Germany.

—. 2010. "Growing Stronger Together: Annual Report 2009-10." FLO, Bonn, Germany.

—. 2011a. "Fact Sheet: Fairtrade Coffee Standards and Pricing." FLO, Bonn, Germany.

—. 2011b. "Fairtrade Responds to Announcement by Fair Trade USA." FLO, Bonn, Germany.

Fridell, Gavin. 2007a. "Fair-trade Coffee and Commodity Fetishism: The Limits of Marketdriven Social Justice." Historical Materialism--Research in Critical Marxist Theory 15:79-104. 
-. 2007b. Fair Trade Coffee: The Prospects and Pitfalls of Market-Driven Social Justice. Toronto: University of Toronto Press.

Fridell, Mara, Ian Hudson, and Mark Hudson. 2008. "With Friends Like These: The Corporate Response to Fair Trade." Review of Radical Political Economy 40:8-34.

Friedland, William H. 1994. "The New Globalization: The Case of Fresh Produce." Pp. 210-231 in From Columbus to ConAgra: The Globalization of Food and Agriculture, edited by A. Bonanno, et. al. Lawrence: University Press of Kansas.

Friedmann, Harriet. 1994. "Distance and Durability: Shaky Foundations of the World Food Economy." Pp. 258-276 in The Global Restructuring of Agro-Food Systems, edited by P. McMichael. Ithaca, NY: Cornell University Press.

Frundt, Henry J. 2009. Fair Bananas! Farmers, Workers, and Consumers Strive to Change an Industry. Tucson: University of Arizona Press.

Fung, Archon, Dara O'Rourke, and Charles Sabel. 2001. Can We Put an End to Sweatshops? Boston: Beacon Press.

Gamson, Howard. 1968. Power and Discontent. Homewood, IL: Dorsey Press.

—. 1975. The Strategy of Social Protest. Homewood, IL: Dorsey Press.

Gereffi, Gary, John Humphrey, and Timothy Sturgeon. 2005. "The Governance of Global Value Chains." Review of International Political Economy 12:78-104.

Gereffi, Gary and Miguel Korzeniewicz. 1994. "Commodity Chains and Global Capitalism." Westport, CT and London: Praeger.

Goigoi, Palavi 2008. "Is Fair Trade Becoming 'Fair Trade Lite'?" Business Week, June 18. 
Goodman, David and Michael Watts. 1994. "Reconfiguring the Rural or Fording the Divide?: Capitalist Restructuring and the Global Agro-Food System." Journal of Peasant Studies 22:1-49.

Gulbrandsen, Lars. 2004. "Overlapping Public and Private Governance: Can Forest Certification Fill the Gaps in the Global Forest Regime?" Global Environmental Politics 4:75-99.

Guthman, Julie. 2004. Agrarian Dreams: The Paradox of Organic Farming in California. Berkeley, California: University of California Press.

—. 2007. "The Polanyian Way? Voluntary Food Labels as Neoliberal Governance." Antipode 39:456-477.

Guzzi, Jamie. 2005. Fair Trade Campaigner, Global Exchange. Personal Communication. San Francisco, CA, September 27.

Harris, Bill. 2005. President, Cooperative Coffees. Personal Communication. Chicago, IL, October 2, 2005.

Harvey, David. 2005. A Brief History of Neoliberalism. New York: Oxford University Press.

Howard, Philip H. 2009. "Consolidation in the North American Organic Food Processing Sector, 1997 to 2007." International Journal of Sociology of Agriculture and Food 16:13-30.

Hudson, Mark and Ian Hudson. 2004. "Justice, Sustainability, and the Fair Trade Movement: A Case Study of Coffee Production in Chiapas." Social Justice 31:130-146.

ICE Futures. 2010. "Coffee C (KC) Futures, New York Board of Trade." Retrieved December 12, 2010 (http://www.econstats.com/fut/xnyb_em2.htm).

International Labor Rights Forum. 2010. Regarding: FLO "New Standards Framework." Letter to FLO. Washington, DC: International Labor Rights Forum, September 3. 
Jaffee, Daniel. 2007. Brewing Justice: Fair Trade Coffee, Sustainability, and Survival. Berkeley, California: University of California Press.

—. 2010. "Fair Trade Standards, Corporate Participation, and Social Movement Responses in the United States." Journal of Business Ethics 92:267-285.

James, Deborah. 2000. "Java and Justice: Coffee in a Fair Trade Market." NACLA Report on the Americas 34:11-14.

Klein, Naomi. 1999. No Logo: Standing Up to the Brand Bullies. New York: Picador.

Klooster, Dan. 2005. "Environmental Certification of Forests: The Evolution of Environmental Governance in a Commodity Network." Journal of Rural Studies 21:403-417.

McAdam, Doug, John D. McCarthy, and Meyer N. Zald. 1996. Comparative Perspectives in Social Movements: Political Opportunities, Mobilizing Structures, and Cultural Framings. Cambridge: Cambridge University Press.

McMichael, Philip. 1996. "Globalization: Myths and Realities." Rural Sociology 61:25-55.

—. 2000. "The Power of Food." Agriculture and Human Values:21-33.

—. 2007. Development and Social Change (4th edition): Pine Forge Press.

Mutersbaugh, Tad. 2005a. "Fighting Standards with Standards: Harmonization, Rents, and Social Accountability in Certified Agrofood Networks." Environment and Planning A 37:20332051.

—. 2005b. "Just-in-Space: Certified Rural Products, Labor of Quality, and Regulatory Spaces." Journal of Rural Studies 21:389-402.

North, Rodney. 2008. "On Fair Trade 'Fig Leaves': Equal Exchange Speaks Out on Abuse of the Fair Trade System." Retrieved February 28, 2009 (http://www.wedge.coop/newsletter/article/630.html). 
Oxfam America. 2002. "Mugged: Poverty in Your Coffee Cup." Boston: Oxfam America.

Oxfam International. 2004. "Nestlé Profits 2003." Retrieved September 16, 2005

(http://www.maketradefair.com/en/index.php?file=26022003151628.htm).

Pellow, David N. 2001. "Environmental Justice and the Political Process: Movements, Corporations, and the State." Sociological Quarterly 42:47-67.

Polanyi, Karl. 1944. The Great Transformation. Boston: Beacon Press.

Ponte, Stefano. 2002. "The 'Latte Revolution'? Regulation, Markets and Consumption in the Global Coffee Chain." World Development 30:1099-1122.

Raynolds, Laura T. 2000. "Re-Embedding Global Agriculture: The International Organic and Fair Trade Movements." Agriculture and Human Values 17:297-309.

—. 2002. "Consumer/Producer Links in Fair Trade Coffee Networks." Sociologia Ruralis 42:404-424.

—. 2010. "Fair Flowers: Fair Trade and Plantation Relations in Ecuador." Paper Presented at Latin American Studies Association (LASA) Congress, Toronto, Canada, October 6-9. Raynolds, Laura T. and John Wilkinson. 2007. "Fair Trade in the Agriculture and Food Sector: Analytical Dimensions." in Fair Trade: The Challenges of Transforming Globalization, edited by L. T. Raynolds, D. Murray, and J. Wilkinson. New York: Routledge.

Reed, Darryl. 2009. "What Do Corporations Have to Do With Fair Trade? Positive and Normative Analysis From a Value Chain Perspective." Journal of Business Ethics 86:326.

Renard, Marie Christine. 1999a. "The Interstices of Globalization: The Example of Fair Coffee." Sociologia Ruralis 39:484-500. 
—. 1999b. Los Intersticios de la Globalización: Un Label (Max Havelaar) para los Pequenos Productores de Café. Mexico City: Misceláneas.

—. 2003. "Fair Trade: Quality, Market and Conventions." Journal of Rural Studies 19:87-96.

—. 2005. "Quality Certification, Regulation and Power in Fair Trade." Journal of Rural Studies 21:419-431.

-. 2010. "In the Name of Conservation: CAFE Practices and Fair Trade in Mexico." Journal of Business Ethics 92:287-299.

Rice, Paul. 2005. CEO, Transfair USA. Personal Communication. Seattle, WA, April 16.

Rigby, Dan and Sophie Brown. 2007. "Whatever Happened to Organic? Food, Nature and the Market for 'Sustainable' Food." Captalism, Nature, Socialism 18:81-102.

Rosenthal, Jonathan. 2005. Director, Just Works; Co-founder, Equal Exchange Coffee. Personal Communication. Boston, MA, May 27.

—. 2010. "The Future of Fair Trade." Paper Presented at Fair Trade Futures Conference, Boston, MA, September 10-12.

Sassen, Saskia. 1996. Losing Control? Sovereignty in an Age of Globalization. New York: Columbia University Press.

Schurman, Rachel. 2004. "Fighting "Frankenfoods": Industry Opportunity Structures and the Efficacy of the Anti-Biotech Movement in Western Europe." Social Problems 51:243268.

-. 2010. Fighting for the Future of Food: Activists Versus Agribusiness in the Struggle over Biotechnology. Minneapolis: University of Minnesota Press.

Seidman, Gay. 2007. Beyond the Boycott: Labor Rights, Human Rights, and Transnational Activism. New York: Russell Sage Foundation. 
—. 2008. "Transnational Labour Campaigns: Can the Logic of the Market Be Turned Against Itself?" Development and Change 39:991-1003.

Selznick, Philip. 1948. "Foundations of the Theory of Organizations." American Sociological Review 13:25-35.

Sklair, Leslie. 2002. Globalization: Capitalism and Its Alternatives. New York: Oxford University Press.

Starbucks. 2001. "Corporate Social Responsibility Annual Report." Starbucks Coffee, Seattle.

—. 2010. "Starbucks Global Responsibility Report: Goals and Progress 2010." Starbucks Coffee, Seattle.

Starbucks and Transfair USA. 2000. Starbucks and TransFair USA Enter into Breakthrough Alliance to Promote Fair Trade Certified Coffee. Press Release. Oakland, CA and Seattle, WA, April 10.

Talbot, John M. 2004. Grounds for Agreement: The Political Economy of the Coffee Commodity Chain. Lanham: Rowman \& Littlefield Publishers.

Taylor, Peter Leigh. 2005a. "In the Market But Not of It: Fair Trade Coffee and Forest Stewardship Council Certification as Market-Based Social Change." World Development 33:129-147.

—. 2005b. "A Fair Trade Approach to Community Forest Certification? A Framework for Discussion." Journal of Rural Studies 21:433-447.

The Packer. 2009. "Dole Debuts Fair Trade Pineapples, Bananas " The Packer, October 24. Thompson, Craig J. and Gokcen Coskuner-Balli. 2007. "Countervailing Market Responses to Corporate Co-optation and the Ideological Recruitment of Consumption Communities." Journal of Consumer Research 34:135-152. 
Tiffen, Pauline. 2005. Independent Consultant. Personal Communication. Madison, WI, March 4.

Tranchell, Sophi. 2010. Managing Director, Divine Chocolate Ltd. Personal Communication. Boston, MA, September 12.

Tropical Commodity Coalition. 2009. "Coffee Barometer 2009." Tropical Commodity Coalition, The Hague, Netherlands.

Trumpy, Alexa. 2008. "Subject to Negotiation: The Mechanisms Behind Co-optation and Corporate Reform." Social Problems 55:480-500.

Turner, Mandy. 2007. "Society Must Be Protected: Polanyi's 'Double Movement' and the Regulation of Conflict Goods." The Journal of Corporate Citizenship 26:85-99.

Van Dyke, Nella, Sarah A. Soule, and Verta A. Taylor. 2004. "The Targets of Social Movements: Beyond a Focus on the State." Pp. 27-51 in Authority in Contention (Research in Social Movements, Conflicts and Change, vol. 25), edited by Patrick G. Coy: Emerald Group Publishing Limited.

Vidal, John. 2007. "Saving St. Lucia: UK Supermarket Sweeps Up 100m Bananas." The Guardian, February 27.

Weber, Klaus, L.G. Thomas, and Hayagreeva Rao. 2009. "From Street to Suites: How the AntiBiotech Movement Affected German Pharmaceutical Firms." American Sociological Review 74:106-127.

\section{NOTES:}

1 Many observers challenge claims that neoliberal globalization has weakened nation-states, arguing they have been profoundly reconfigured rather than eviscerated, while nonetheless acknowledging the greatly increased power of TNCs (e.g., McMichael 2010; Sassen 1996). 
2 While most third-party certifications are created by NGOs, they can also have a state locus. The USDA organic standards are a prime example of civil society-generated certification being supplanted by governmental oversight.

${ }^{3}$ Nevertheless, some scholars of fair trade view this shift in the locus of SMO energies as problematic, arguing that the nature of the claims civil society can make upon corporate actors is far more limited than the kinds of demands citizens are able to make on even severely constrained states (e.g., Fridell 2007b; Jaffee 2007).

${ }^{4}$ In late 2010, Transfair USA changed its name in to Fair Trade USA, and FLO became Fair Trade International. I use the former names throughout this paper to retain consistency with the interview quotes.

${ }^{5}$ Procter \& Gamble introduced one fair-trade certified coffee as part of its specialty Millstone brand in 2004. J.M. Smuckers purchased P\&G's entire coffee division in 2008. As of that year, fair-trade coffee represented 0.5 percent of the firm's total coffee volume (Tropical Commodity Coalition 2009). Sara Lee has since stopped selling fair-trade coffee entirely.

${ }^{6}$ The 2007-08 FLO increases raised the base price for conventional green coffee (paid to farmer organizations) from $\$ 1.26$ per pound to $\$ 1.35$, and the price for certified organic coffee from $\$ 1.41$ to $\$ 1.55$ per pound.

7 These figures exclude sales of fair-trade crafts and artisanal goods, for which FLO has yet to develop formal certification or standards. In 2010, however, FLO and Transfair USA began to certify fair trade cotton clothing.

${ }^{8}$ Fridell (2007) also addresses the tensions between what he terms the fair trade "system" and the fair trade "network," or social movement. 